\title{
Effect of SiC Powder Additive on Mechanical Properties of Al-Pb Alloy Produced by Mechanical Alloying
}

\author{
Suhair G. Hussein \\ Mechanical Eng.Dep. \\ University of Baghdad, \\ Baghdad, IRAQ \\ suhairaaffmm@yahoo.com \\ Received: $28-F e b .-2018$ \\ http://doi.org/10.29194/NJES.21030389
}

\author{
Nabeel Kadim Abdel Sahib \\ Al-Nahrain University, \\ Baghdad, IRAQ \\ n_k_alsahib@yahoo.com
}

\begin{abstract}
One of the major usages for $\mathrm{Al}-\mathrm{Pb}$ alloy are bearing alloys because of its lubricant behavior of $\mathrm{Pb}$ phase component. Applications of these alloys are in heavy duty, such as boring mills, presses, lathes, milling machines and hydraulic pump bushings. In present work, $\mathrm{SiC}$ powder was selected as additive for improving the mechanical properties of $\mathrm{Al}-\mathrm{Pb}$ alloy that produced by mechanical alloying method. The percentage weight of $\mathrm{SiC}$ powder are $(2.5,5,10,15 \%)$ which mixing together with $\mathrm{Al}-\mathrm{Pb}$ alloy for two hours in ball milling device, then compacted and sintering to obtain the improved alloy, and examine the mechanical properties (compressive strength and microhardness) of produced alloy . Results show that the additive of $\mathrm{SiC}$ powder on the $\mathrm{Al}-\mathrm{Pb}$ alloy lead to improve the microhardness which increased with increased the percentage of additive, in the other hand, the compressive strength had a reverse effective with increased the percentage of $\mathrm{SiC}$ powder.
\end{abstract}

Keywords: Al-Pb alloy, Mechanical Alloying, $\mathrm{SiC}$ Powder, Mechanical Properties.

\section{Introduction}

Aluminum -lead alloys are considered as bearing materials of $21 \mathrm{st}$ century[1].One of the major usages for $\mathrm{Al}-\mathrm{Pb}$ alloy are bearing alloys because of its lubricant behavior of $\mathrm{Pb}$ phase component. In general, homogeneous and disperse distribution of fine lubrication phase in Aluminum matrix is important for wear properties [2]. Al-Pb bearing alloy have been used in automobile industry, and the improving of mechanical properties of this alloy such as the strength and wear properties was done by adding some alloying element such as copper and magnesium . But because of the different in specific gravity and immiscibility between $\mathrm{Al}$ and $\mathrm{Pb}[3]$, which greatly increase the kinetic of lead segregation during melting and freezing [4], this lead to difficult manufacturing of this type of alloys [3]. There are different methods (rapid solidification, stir cast, rheo cast, powder metallurgy, and hot extrusion ) may be used to improve microstructure homogeneity and to get finer size of $\mathrm{Pb}$ phase in $\mathrm{Al}-\mathrm{Pb}$ alloys because the homogeneous distribution of Lead in Aluminum matrix could not be easily obtained by traditional casting processes [5].

Mechanical alloying is one of the efficient methods when it compared with the previous methods because it dependent on the mechanical forces such as compressive force, shear or impact to effect particle size reduction of bulk materials. This is sometimes referred to as mechanical alloying or ball milling which is one of the mechanical alloying method had been used since 1970 to produce successfully new alloys bond on powder particles as a method for material synthesis [6]. Aluminum and its alloys are widely used in the fabrication of MMCs and have reached the industrial production stage. The emphasis has been given on developing affordable Al-based MMCs with various hard and soft reinforcements ( $\mathrm{SiC}, \mathrm{Al} 2 \mathrm{O} 3$, zircon, graphite, and mica) because of the likely possibilities of these combinations in forming highly desirable composites [7]. P.Kumar, et al in 2015 , add $\mathrm{SiC}$ as a persentage (5\% 10\% 15\% and 20\%) by weight to aluminum alloy. Hardness and compressive strength are increased as the percentage addition of $\mathrm{SiC}$ increased [8]. B.Venkatesh1, B.Harish2 in 2015 get increasing in hardness of pure aluminum when adding $\mathrm{SiC}$ particles as $10 \%$ and $15 \%$ by weight. The increasing in hardness is related to increase in $\mathrm{SiC}$ percentage added [9]. Ramesh B. T , et al in 2015 studied the effect of $\mathrm{SiC}$ addition to $\mathrm{Al} 6061$ alloy. Different weight percentages $(5 \%, 10 \%$, and $15 \%$ ) of $\mathrm{SiC}$ were added. The results showed that an increasing in hardness and decreasing in wear rate directly proportional to the added percentage of $\mathrm{SiC}$ [10]. S.E. Ede1, et al in 2015 studied the effect of adding $(\mathrm{SiC})$ in Nano particle size as a reinforcement to the produced product of AA2618 alloy. ( $\mathrm{SiC}$ ) was added as 5\%, 10\%, $15 \%, 20 \%, 25 \%$ and $30 \%$, as weight to the route of casting. It showed an increase in hardness, yield strength, Young modulus ,density and tensile strength with increasing the addition of $\mathrm{SiC}$. While it showed a decreasing in ductility with increasing the addition of $\mathrm{SiC}$. It was observed that the addition of $\mathrm{SiC}$ has a limit 
called critical limit. Exceeding this limit gave reverse results due to bulk formation of $\mathrm{SiC}$ [11]. G. Hemath Kumar, et al, in 2010 showed that the addition of $\mathrm{SiC}$ IN $5 \%$ to $30 \%$ of weight percentages to aluminum as base metal increasing the hardness in direct proportion with increasing $\mathrm{SiC}$ additive [12]. Dr. Jameel Habeeb Ghazi in 2013 investigated the effect of adding $\mathrm{SiC}$ to $\mathrm{Al}-$ $\mathrm{Si}$ alloy. The addition of $\mathrm{SiC}$ was $7 \%, 14 \%$ and $21 \%$ as weight percentage to the molting of the casting. Improving the mechanical properties has been obtained due to this addition represented by increasing the hardness, yield and tensile strength [13]. The aim of present study is enhancing the mechanical properties of $\mathrm{Al}-\mathrm{Pb}$ alloy by adding $\mathrm{SiC}$ particles with various weight percentages.

\section{Experimental Work}

Three types of metals $\mathrm{Al}, \mathrm{Pb}$, and $\mathrm{Cu}$ with different particle size were used. Table 1shows the average particle size and purity of powders. These metals were mixed together with specific weight percentage $(85.5 \% \mathrm{Al}, 10 \% \mathrm{~Pb}$ and $4.5 \% \mathrm{Cu})$.

Table (1): Particle size and purity of powders

\begin{tabular}{|c|c|c|}
\hline Element & $\begin{array}{c}\text { Average particle } \\
\text { size (um) }\end{array}$ & $\begin{array}{c}\text { Purity } \\
(\mathbf{\%})\end{array}$ \\
\hline Aluminum $(\mathrm{Al})$ & 20 & 99.90 \\
\hline Copper $(\mathrm{Cu})$ & 25 & 99.89 \\
\hline Lead $(\mathrm{Pb})$ & 95 & 99.86 \\
\hline
\end{tabular}

Powder mixture were mixed in a stainless steel vial used hardened steel balls in a ratio of powder to steel ball $(\mathrm{p} / \mathrm{b})$ equal to $(1 / 10)$ milled in a planetary mill with rotation speed $250 \mathrm{rpm}$ with protective Argon atmosphere for two hours. The powder produced by milling was compacted by a hydraulic press $400 \mathrm{MPa}$ to produce billets with rectangular cross section $\left(15 \times 15 \mathrm{~mm}^{2}\right)$. The billets were sintered at $450^{\circ} \mathrm{C}$ with soaking time 30 minutes in a tube furnace with Argon protective (2 $\mathrm{L}$ /minute flow rate). The produced billets were assessment by compression strength and Vickers micro hardness test and the results were recorded.

$\mathrm{SiC}$ powder with average grain size $(3 \mu \mathrm{m})$ and purity of $(97.9 \%)$ were selected to add to $\mathrm{Al}-\mathrm{Pb}$ alloy because of that it considered the best additive to create better mechanical properties. Dependent on the previous researchers, the micro $\mathrm{SiC}$ was added to the starting powder at various percentage of weight $(2.5,5,10$, and 15\%) respectively. The mixture was mechanically alloyed by ball milling with the same condition used and the produced powder was compacting and sintering at the same previous values. The produced alloys were assessment by the same type of tests used, and then the results obtained were compared with the results obtained before additive.

\section{Result and Discussin}

Fig.1 and 2 show the SEM and EDX respectively of $\mathrm{SiC}$ powder that added to constitutes for improving the mechanical properties.

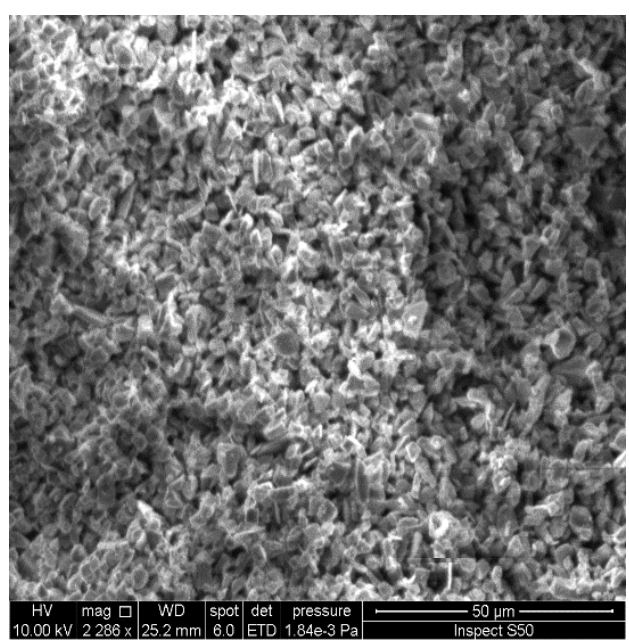

Figure 1: SEM of SiC powder

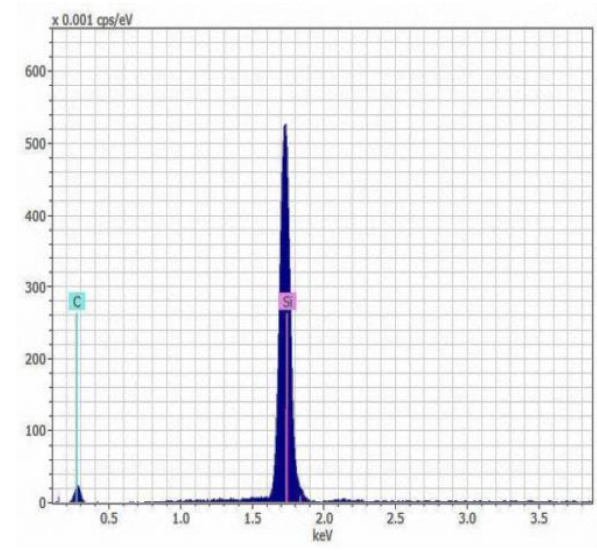

Figure 2: EDX of SiC powder

The particles of $\mathrm{SiC}$ powder have rectangular like shape as seen in figure 1, EDX of $\mathrm{SiC}$ powder indicate that high purity powder as shown in figure 2. SEM of produced alloy after mechanical alloying, compacting and sintering is shown in figure 3, and from this figure it can be see the distribution of $\mathrm{SiC}$ particles through base matrix. The results of billets produced from mechanical alloying before adding the $\mathrm{SiC}$ powder were recorded in table 2 . The results after additive the $\mathrm{SiC}$ powder showed that the micro hardness increased with increasing the percentage of addition as shown in Fig.4, and the maximum addition of $\mathrm{SiC}$ powder indicate $72 \mathrm{HV}$, that 
is mean the percentage of improvement of micro hardness is $44 \%$ approximately.

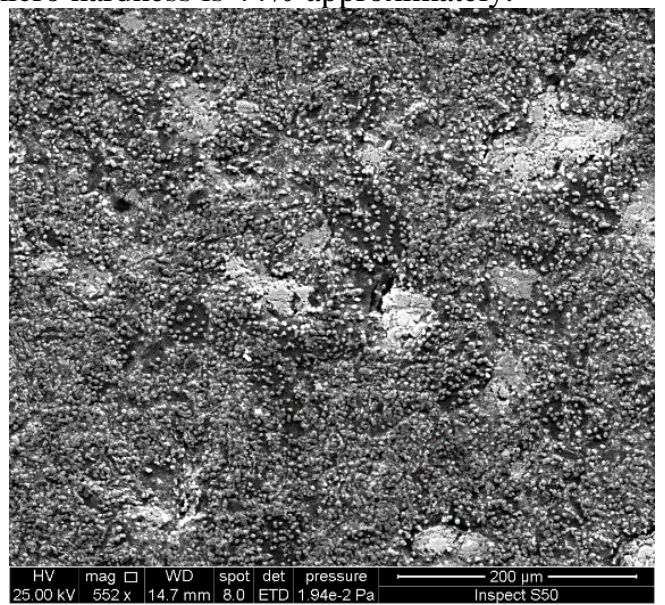

Figure3: SEM for alloy at $15 \% \mathrm{SiC}$ powder

Table (2): Mechanical properties of $\mathrm{Al}-\mathrm{Pb}$ alloy before additive

\begin{tabular}{|c|c|c|c|}
\hline Property & $\begin{array}{c}\text { Average } \\
\text { Hardness } \\
\text { (HV) }\end{array}$ & $\begin{array}{c}\text { Ultimate } \\
\text { Compression } \\
\text { strength } \\
(\mathrm{MPa})\end{array}$ & $\begin{array}{c}\text { Ductility } \\
\%\end{array}$ \\
\hline $\begin{array}{c}\text { Before } \\
\text { additive }\end{array}$ & 50 & 191 & 12.5 \\
\hline
\end{tabular}

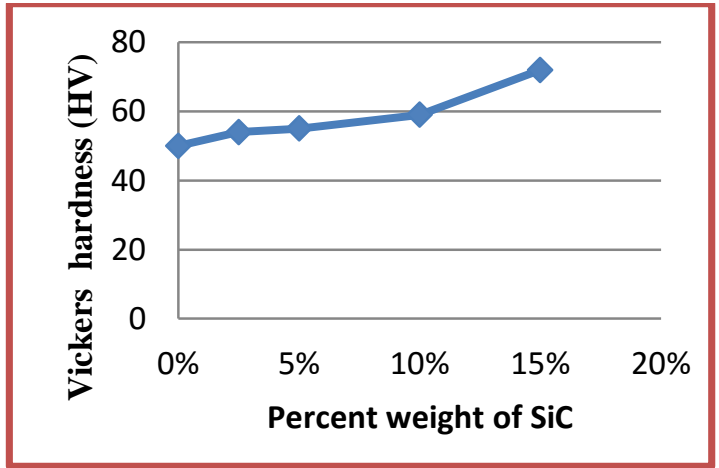

Figure 4: Micro hardness verses percentage weight of SiC powder

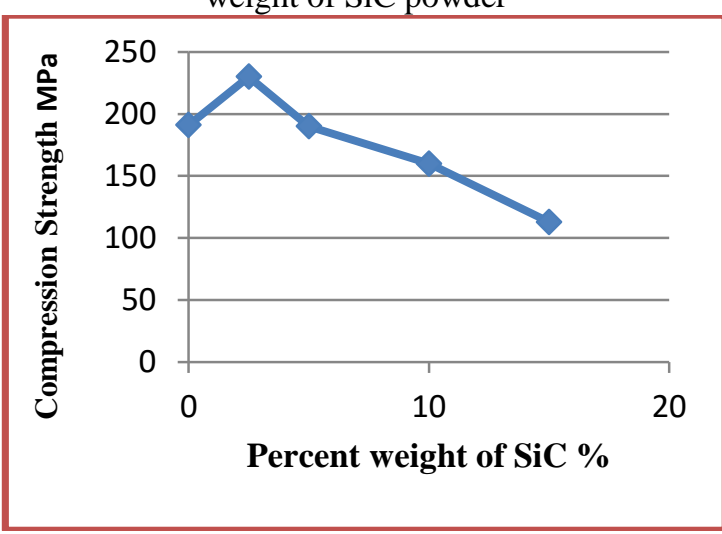

Figure 5: Compressive strength verses percentage weight of $\mathrm{SiC}$ powder

This raising of hardness due to hard ceramic particles of additives which led to higher hardness in produced alloy. This confirm to results of $\mathbf{P}$. Kumar, et al. [8] and B. Venkatesh, et al. [9]. The results of compression strength for produced alloy is showed that the increasing of percentage of $\mathrm{SiC}$ powder associating with lowering down in compression strength except the percentage of $2.5 \%$ which has increasing in compression strength about $20 \%$ as shown in figure 5. This is due to the particle shape of $\mathrm{SiC}$ powder was not spherical or rounded as shown in figureland the particles have sharp edges. These sharp edges which caused stress concentration, leading to reduce the strength with increased the percentage weight of $\mathrm{SiC}$ powder. This results nearby T. A. Khalifa [14] who used SiC powder as reinforced of AA6063 aluminum alloy.

Also, ductility of alloy after additives decreased with raising of ceramics additives as shown in figure 6 due to increasing of hardness.

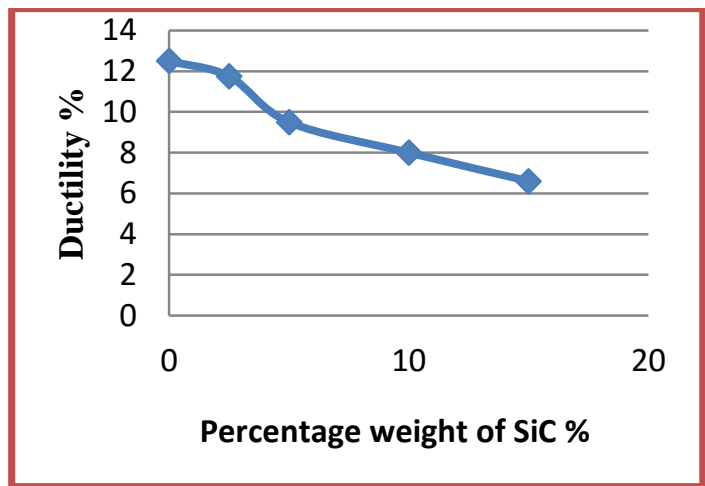

Figure 6: Ductility verses percentage weight of $\mathrm{SiC}$ powder

\section{Conclusions}

- Mechanical alloying is considered as an attractive method used to produce $\mathrm{Al}-\mathrm{Pb}$ alloy.

- Addition of $\mathrm{SiC}$ powder in different percentages raised the micro hardness, the maximum additive led to $44 \%$ enhancement.

- In the other hand the increasing of additive of $\mathrm{SiC}$ powder had a bad effect on compression strength except for small quantities such as $2.5 \%$ which led to increase the compression strength about $20 \%$, so there is recommended to use this percentage weight of $\mathrm{SiC}$ powder which is considered as the best percentage of additive that is combination enhancement for the compression strength and micro hardness

- Ductility is lowering down for all percentage of additives.

\section{References}


[1] Pathak J. P., "Proceeding of $2^{\text {ed }}$ International conference of Industrial Tribology, Hyderabad, India, Dec1-4 1999, pp.535-537.

[2] M. Zhu*, M.Q. Zeng, Y. Gao, L.Z. Ouyang, B.L. Li "Microstructure and wear properties of $\mathrm{Al}-\mathrm{Pb}-\mathrm{Cu}$ alloys prepared by mechanical alloying", Elsevier Science-Wear, Vol. 253, 2002, pp.832-838.

[3] Ch V S $\quad$ H $\quad$ S $\quad$ R Sastry and G Ranga Janardahana, "Densification behavior of Al$\mathrm{Pb}$ alloys- A study of effect of Certain Process Parameters", Indian Journal of Engineering \& Materials Sciences. Vol.17, 2010, pp.56-60.

[4] Voind Kumar, Albert Yanthan, P. R. Soni and T. V. Rajan "Wear Resistance of Leaded Aluminum Alloy Prepared by Mechanical Alloying", Indian Journal of Engineering \& Materials Sciences. Vol.10, 2003, pp.413-415.

[5] Hayder Ali Hussein and Adnan N. Abood“" The Role of Nano Particles Additives on the wear Properties of Al- $\mathrm{Pb}$ alloy" Chemistry and Materials Research, Vol.7(7) 2015, pp.86-104.

[6] K. V. Nagesha, Rajanish M. and D. Shivappa, “ A Review On Mechanical Alloying", International Journal of Engineering Research and Applications (IJERA), Vol. 3(3)2013, pp.921-924.

[7] Dunia Abdul Saheb, "Aluminum Silicon Carbide and Aluminum Graphite Particulate Composite", ARPN Journal of Engineering and Applied Sciences, Vol. 6(10)2011, pp.41-46.

[8] P. Kumar, S. Ranjithkumar, C. Shanmugam, M. Jayaram, Vijayakumar. S and V. Karthik, "Experimental Investigation of Aluminum Silicon Carbide Composites by Powder Metallurgy
Technique", International Journal of Innovative Research in Technology, Vol. 1 (12) 2015. pp. 527-536.

[9] B. Venkatesh and B. Harish, "Mechanical Properties of Metal Matrix Composite (Al/SiCp) Particles Produced by Powder Metallurgy" , International Journal of Engineering Research and General Science Vol. 3(1) 2015, pp.1277-1284.

[10] Ramesh B. T., Arun Kumar M. B. and R. P. Swamy, "Dry Sliding Wear Test Conducted On Pin-On-Disk Testing Setup For Al6061-SiC Metal Matrix Composites Fabricated by Powder Metallurgy, IJISET International Journal of Innovative Science, Engineering \& Technology, Vol. 2(6), 2015, pp. 264-270.

[11] S. E. Ede, J. U. Odo, I. D. Adiele, J. N. Ani, C.W. Onyia and B. A. Okorie, “ Effects of Silicon Carbide (SIC) Nano Particulates Addition on Mechanical Properties of Aa2618 Alloy" International Journal of Scientific and Research Publications, Vol. 5, Issue 4, 2015, pp.1-6.

[12] G. Hemath Kumar, B. R. Ramesh Bapu, R. Sagar and H. Mohit, "The Abrasive Wear Behaviour of Al-SiCp Composites for Automotive Parts", IEEE , Vol.978, 2010, pp.54-59.

[13] Jameel Habeeb Ghazi, "Production and Properties of Silicon Carbide Particles Reinforced Aluminum Alloy Composites" International Journal of Mining, Metallurgy \& Mechanical Engineering (IJMMME) Vol. 1, Issue 3, 2013, pp.191-194.

[14] Tarek A. Khalifa, Tamer S. Mahmoud "Elevated Temperature Mechanical Properties of Al Alloy AA6063/SiCp MMCs", WCE, Vol.II, 2009, PP. 1 - 3.

\section{تأتير اضافة مسحوق كاربيد السليكون على الخواص الميكاتيكية لسبيكة المنيوم - رصاص محضرة بطريقة الخلط الميكانيكي الثيكانية}

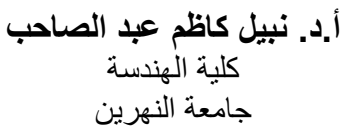

جامعة النهرين

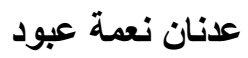

الكلية التقنية /بغداد

الجامعة التقنية الوسطى القغية

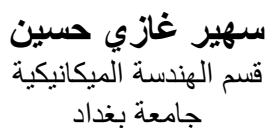

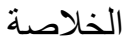

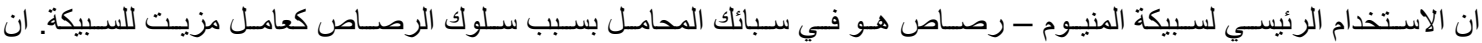

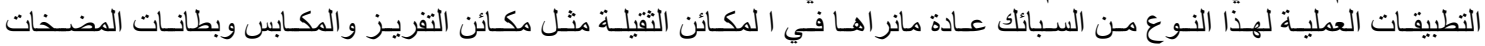

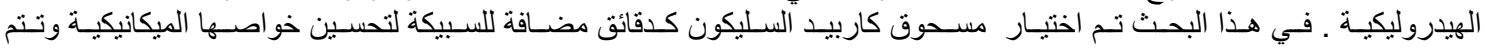

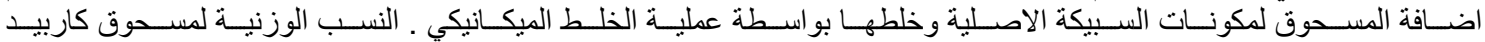

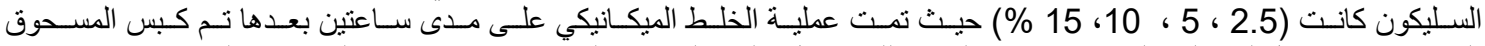

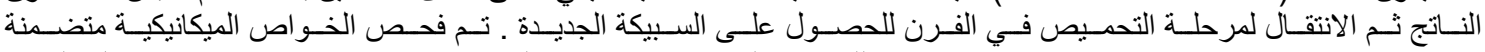

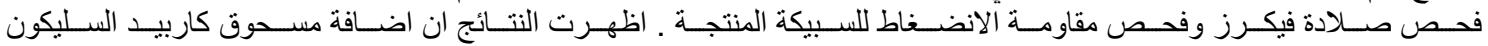

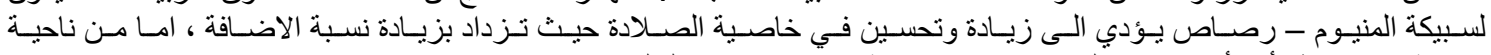

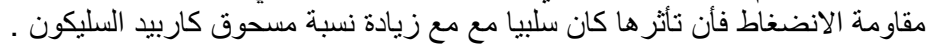

